\title{
URGENSI PENGGOLONGAN NARAPIDANA DALAM LEMBAGA PEMASYARAKATAN
}

\author{
Urgency of Class of Prisoners in the Correctional Institution
}

\author{
Rahmat Hi. Abdullah \\ Fakultas Hukum, Universitas Gadjah Mada \\ email: abdullahrahmat05@gmail.com
}

\begin{abstract}
In the new system of coaching inmates, inmate treatment is applied as a subject as well as the object. The subjects here as similarities, parallels, equally as human beings, are equal as creatures of God, both as a specific creature, capable of thinking and able to make decisions. As objects because basically there is no difference in the coaching position, the difference in coaching and not as human beings. Based on the information, the classification of prisoners according to the correctional objectives with regard to the guidance and upbringing. Guidance and education will be maximized if no classification of prisoners. For example, the classification of inmates by age. Prisoners who are still children or aged under 18 years (correctional education of children), coaching and education in contrast to older age. They got special treatment and should be fostered in children's prisons.
\end{abstract}

Keywords: Inmates, Correctional Institutions, Classification

\section{abstrak}

Dalam sistem baru pembinaan narapidana, perlakuan narapidana diterapkan sebagai subyek sekaligus obyek. Subyek di sini sebagai kesamaan, kesejajaran, sama-sama sebagai manusia, sama-sama sebagai makhluk Tuhan, sama-sama sebagai makhluk yang spesifik, yang mampu berfikir dan mampu membuat keputusan. Sebagai obyek karena pada dasarnya ada perbedaan kedudukan dalam pembinaan, perbedaan dalam pembinaan dan bukan sebagai manusianya. Berdasarkan keterangan tersebut maka penggolongan narapidana yang sesuai dengan tujuan pemasyarakatan berkaitan dengan bimbingan dan didikan. Bimbingan dan didikan akan lebih maksimal jika ada penggolongan narapidana. Sebagai contoh penggolongan narapidana berdasarkan umur. Narapidana yang masih anak-anak atau usia di bawah 18 tahun (anak didik pemasyarakatan), pembinaan dan didikannya berbeda dengan usia yang lebih tua. Mereka mendapat perlakuan khusus sehingga harus dibina dalam lapas anak. 
Kata kunci:, Narapidana, Lembaga Permasyarakatan, Penggolongan

\section{A. Pendahuluan}

Dalam rangka pembaharuan sistem dan pelaksanaan pidana, maka istilah sistem kepenjaraan telah diubah menjadi sistem pemasyarakatan, dan istilah penjara diganti menjadi lembaga pemasyarakatan. Demikian pula dalam hal perlakuan terhadap narapidana mengalami perubahan dari pembalasan menjadi pembinaan. Oleh karena pembinaan narapidana berdasarkan sistem pemasyarakatan bertujuan agar narapidana menjadi warga masyarakatan yang baik dan bertanggung jawab, menyadari kesalahan dan tidak lagi melakukan perbuatan yang melanggar hukum.

Berkembangnya peradaban manusia membawa pengaruh yang besar dalam seluruh aspek kehidupan manusia, termasuk berkembangnya hak asasi manusia. Dalam hukum pidana, perkembangan ini terjadi antara lain dengan terjadinya pergeseran paradigma. Pergeseran paradigma dalam hukum pidana mulai dari peradaban (aliran) klasik, aliran modern, aliran neo klasik dan aliran perlindungan masyarakat. Pergeseran paradigma tersebut menyebabkan terjadinya pergeseran tentang konsep dasar pemidanaan. Hal ini disebabkan adanya tuntutan perkembangan peradaban manusia sebagaimana tersebut di atas.

Secara umum dapat dikemukakan bahwa pergeseran tentang konsepsi pemidanaan itu cenderung dimulai dari konsepsi yang bersifat menghukum yang berorientasi ke belakang, bergeser ke arah gagasan/ide membina yang berorientasi ke depan. Di indonesia pergeseran orientasi dalam pemidanaan ini nampak dengan adanya penggantian istilah penjara menjadi istilah pemasyarakatan. Penggantian ini dimaksudkan agar pembinaan narapidana berorientasi pada tindakan yang lebih manusiawi dan disesuaikan dengan kondisi narapidana. Rumah penjara yang dulunya sebagai wadah bagi narapidana yang merupakan warisan pemerintahan kolonial Belanda dianggap tidak sesuai dengan nilai-nilai yang dianut oleh masyarakat Indonesia.

Pidana penjara merupakan salah satu sanksi pidana pokok yang diterapkan di Indonesia. Pidana pokok yang lain adalah pidana denda, pidana kurungan dan pidana mati. Pidana penjara dilakukan di Lembaga pemasyarakatan. Di lembaga pemasyarakatan, para narapidana akan dibina dan diharapkan setelah habis masa hukumannya, keluar dari lembaga pemasyarakatan menjadi orang baik.

Lembaga Pemasyarakatan adalah tempat yang sangat berpengaruh terhadap pembinaan para narapidana dan bagaimana narapidana setelah keluar dari lembaga pemasyarakatan. Karena saat ini sering terdengar bahwa lembaga pemasyarakatan adalah sekolah tinggi ilmu kejahatan. Narapidana yang dipenjara dalam lembaga pemasyarakatan akan belajar melakukan 
kejahatan dengan level lebih tinggi dan dengan perencanaan yang lebih matang dengan narapidana lainnya. Dimungkinkan setelah keluar dari lembaga pemasyarakatan akan mengulangi kejahatan (residivis).

Pembinaan narapidana adalah sebuah sistem. Sebagai suatu sistem, maka pembinaan narapidana memunyai beberapa komponen yang bekerja saling berkaitan untuk mencapai suatu tujuan. Sedikitnya ada empat belas komponen yaitu: falsafah, dasar hukum, tujuan, pendekatan sistem, klasifikasi, pendekatan klasifikasi, perlakuan terhadap narapidana, orientasi pembinaan, sifat pembinaan, remisi, bentuk bangunan, narapidana, keluarga narapidana, dan Pembina/pemerintah ${ }^{1}$.

Dalam sistem baru pembinaan narapidana, perlakuan narapidana diterapkan sebagai subyek sekaligus obyek. Subyek di sini sebagai kesamaan, kesejajaran, sama-sama sebagai manusia, sama-sama sebagai makhluk Tuhan, sama-sama sebagai makhluk yang spesifik, yang mampu berfikir dan mampu membuat keputusan. Sebagai obyek karena pada dasarnya ada perbedaan kedudukan dalam pembinaan, perbedaan dalam pembinaan dan bukan sebagai manusianya ${ }^{2}$.

Perbedaan dalam pembinaan salah satu contohnya adalah dengan penggolongan narapidana. Penggolongan narapidana mempermudah proses pembinaan karena sering kali pembinaan bukan dari pembina tetapi narapidana sendiri atau sekelompok narapidana.

Di Indonesia terdapat penggolongan lembaga pemasyarakatan, yaitu lapas umum dan lapas khusus seperti Lapas Perempuan, Lapas Anak, Lapas Narkotika dan Lapas untuk tindak pidana berat seperti yang ada di Nusakambangan Cilacap. Namun tidak di semua daerah di Indonesia memunyai lapas-lapas khusus. Biasanya daerah yang tidak memunyai lapas khusus contohnya untuk narapidana anak, maka akan dititipkan di lapas anak di daerah lain yang paling dekat.

Berdasarkan latar belakang di atas maka penulis tertarik terhadap isu hukum, yaitu: 1) alasan yang menyebabkan adanya penggolongan narapidana; dan 2) penggolongan narapidana tujuan pemidanaan dan tujuan pemasyarakatan akan terpenuhi. Metode yang digunakan adalah yuridis, yaitu dengan menelaah bahan sekunder seperti buku ilmiah maupun undangundang dan lain-lain.

\section{B. Pembahasan}

\section{Dasar Penggolongan Narapidana}

Sifat pidana penjara dimaksudkan melukiskan watak masing-masing jenis pidana agar dapat dibedakan antara pidana penjara dengan sifat pidana

\footnotetext{
${ }^{1}$ C.I. Harsono Hs, System Baru Pembinaan Narapidana, (Jakarta: Djambatan, 1995), hlm. 5.

${ }^{2}$ Ibid, hlm. 19.
} 
lain, misalnya pidana mati, hukuman membayar bunga dan ganti rugi dalam utang piutang. Usaha untuk menyoroti terhadap kedirian, peranan dan manfaat pidana penjara dimaksudkan untuk melukiskan agar tida kehilangan sifat dasarnya sebagai suatu pidana sekalipun menerima pengaruh perkembangan keadaan kriminologis dan sosiologis yang ada di sekitarnya, bahkan dari pengaruh tersebut juga dapat mengarahkan perlakuannya agar memunyai hasil guna dan daya guna bagi upaya ketertiban hukum serta kesejahteraan masyarakat.

Pidana penjara merupakan jenis sanksi pidana yang paling banyak ditetapkan dalam peraturan perundang-undangan pidana selama ini. Dari seluruh ketentuan KUHP yang memuat delik kejahatan yaitu sejumlah 587, pidana penjara tercantum di dalam 575 perumusan delik (kurang lebih 97,96 $\%$ ), baik dirumuskan secara tunggal maupun dirumuskan secara alternatif dengan jenis-jenis pidana lainnya. ${ }^{3}$ Hal ini membuktikan bahwa pidana penjara masih merupakan salah satu sanksi yang menjadi primadona oleh perumus undang-undang dalam setiap perumusan sanksi dalam peraturan perundang-undangan dengan harapan bahwa hal itu dapat menimbulkan efek penjeraan.

Bahkan pelaksanaan pidana penjara tercermin dalam pembaharuan hukum pidana sebagaimana yang dikemukakan oleh Bambang Poernomo. ${ }^{4}$ Pertama, pidana tetap menjadi pidana dan berorientasi ke depan melalui usaha ke arah pemasyarakatan, sehingga tidak hanya sekedar pidana perampasan kemerdekaan akan tetapi mengandung upaya-upaya bersifat baru yang dirumuskan sepuluh butir prinsip pemasyarakatan. Kedua, pelaksanaan pidana penjara dengan sistem pemasyarakatan sebagai tujuan harus memperhatikan aspek perbuatan melanggar hukum dan aspek manusianya sekaligus menunjukkan dengan dasar teori pemidanaan, menganut asas pengimbangan atas perbuatan dan sekaligus memperlakukan narapidana sebagai manusia sekalipun telah melanggar hukum. Ketiga, pengembangan pelaksanaan pidana penjara dengan sistem pemasyarakatan dengan segala kelemahannya, bukanlah untuk mencari jalan keluar dengan menghapus pidana penjara dan perlakuan cara baru terhadap narapidana, disertai teknik dan metode dalam rangka pembaharuan pidana yang bersifat universal. Keempat, sistem pemasyarakatan sebagai proses melibatkan hubungan interrelasi, interaksi dan integritas antara komponen petugas, penegak hukum yang menyelenggarakan proses pembinaan, dan komponen masyarakat beserta budaya yang ada di sekitarnya dengan segala potensinya untuk berperan serta membantu pembinaan sesuai dengan sepuluh prinsip

\footnotetext{
${ }^{3}$ Barda Nawawi Arief, Kebijakan Legislatif Dalam Penanggulangan Kejahatan Dengan Pidana Penjara, (Yogyakarta: Genta Publishing, 2010), hlm 71

${ }^{4}$ Syaiful Bahri, Perkembangan Stelsel Pidana Indonesia, (Yogyakarta: Total Media, 2009), hlm. 80 .
} 
pemasyarakatan. Kelima, pemasyarakatan sebagai metode memunyai tata cara yang direncanakan untuk menyelenggarakan pembinaan/bimbingan tertentu bagi kepentingan masyarakat dan individu narapidana yang bersangkutan melalui upaya-upaya remisi, asimilasi, integrasi, cuti prerelease treatment, lepas bersyarat, after care dan program pendidikan, latihan, keterampilan yang realisasinya menjadi indikator dari pelaksanaan pidana penjara dengan sistem pemasyarakatan. Keenam, upaya pembinaan terpidana, berupa remisi dan cuti, seharusnya dikembangkan lebih efektif, karena bukan sekedar pemberian kelonggaran pidana dengan kemurahan hati, melainkan sebagai indikator awal pembaharuan harus dimanfaatkan sedemikian rupa agar narapidana menyadari makna pembinaan melalui sistem pemasyarakatan. Ketujuh, pokok pikiran pembaharuan pidana penjara yang diterapkan dengan sistem pemasyarakatan belum didukung oleh kekuatan hukum undang-undang.

Pelaksanaan pidana penjara dan perlakuan cara baru terhadap narapidana, dijalankan dengan pembinaan melalui proses penahapan baik proto type dua purpose dan proto type multy purpose sejak narapidana telah mencapai tingkat pengawasan minimum (munimum security). ${ }^{5}$ Dilihat dari segi keamanan dan pembinaan terhadap narapidana di Lembaga Pemasyarakatan serta untuk menjaga pengaruh negatif yang dapat berpengaruh terhadap narapidana lainnya maka penting untuk adanya penggolongan narapidana.

Pasal 12 Undang-Undang Nomor 12 Tahun 1995 tentang Pemasyarakatan menentukan bahwa dalam rangka pembinaan terhadap narapidana di Lembaga Pemasyarakatan dilakukan penggolongan atas dasar: ${ }^{6}$

a. umur;

b. jenis kelamin;

c. lama pidana yang dijatuhkan;

d. jenis kejahatan; dan

e. kriteria lainnya sesuai dengan kebutuhan atau perkembangan pembinaan.

Penempatan seorang tahanan pada prinsipnya jika dilihat dari aspek pengamanan seperti yang telah disebutkan sebelumnya sangatlah berpengaruh terhadap privasi tahanan tersebut, maka semakin longgar kesempatan yang diberikan pada suatu tahapan pengamanan biasanya tahanan tersebut semakin berpengaruh di lingkungan tempat penahanannya. Dengan semakin lama orang ditahan pada suatu penjara tertentu maka akan semakin berpengaruh di penjara tersebut karena semakin lama seseorang tahanan menjadi tahanan, maka biasanya pengawasan terhadap dirinya

\footnotetext{
${ }^{5}$ Aruan Sakidjo, Bambang Poernomo, Hukum Pidana Dasar Aturan Umum Hukum Pidana Kodifikasi, (Yogyakarta: Ghalia Indonesia, 1990), hlm. 85.

${ }^{6}$ Lihat Pasal 12 ayat (1) Undang-Undang Nomor 12 Tahun 1995 tentang Pemasyarakatan.
} 
semakin berkurang dan oleh banyak tahanan kelonggaran pengawasan tersebut dianggap bahwa yang bersangkutan cukup memunyai pengaruh. Oleh sebab itu penempatan tahanan berdasarkan penggolongan sebagaimana disebutkan di atas penting dilakukan untuk menghindari gangguan keamanan dan ketertiban dalam lingkungan Rumah Tahanan (RUTAN) dan Lembaga Pemasyarakatan (LAPAS).

Sistem pemasyarakatan dan peraturan standar minimum bagi perlakuan terhadap narapidana menganut filosofi penghukuman yang diwarnai pendekatan rehabilitatif, yaitu pendekatan yang menganggap pelaku pelanggar hukum sebagai pesakitan dan karenanya harus disembuhkan. Dalam hal ini hakikat pemasyarakatan sesuai dengan falsafah pemidanaan modern yaitu "treatment". Treatment lebih menguntungkan bagi penyembuhan penjahat, sehingga tujuan dari sanksi bukanlah menghukum, melainkan memperlakukan atau membina pelaku kejahatan.

Melalui sistem pemasyarakatan ini pembinaan yang dilakukan terhadap narapidana lebih bersifat manusiawi dengan tetap menjunjung tinggi harkat dan martabatnya sebagai manusia. Perlakuan ini dimaksudkan untuk menempatkan narapidana sebagai sunjek di dalam proses pembinaan dengan sasaran akhir mengembalikan narapidana ke tengah-tengah masyarakat sebagai orang yang baik dan berguna (resosialisasi). Proses tersebut salah satunya dapat dilihat dalam upaya penggolongan narapidana sebagai ide individualisasi pidana dalam pembinaan narapidana berdasarkan sistem pemasyarakatan. Jadi dapatlah dikatakan bahwa ide adanya penggolongan narapidana sebagaimana ditentukan Pasal 12 UU No. 12 Tahun 1995 tentang pemasyarakatan adalah untuk individualisasi pidana yang bertujuan membina narapidana sesuai dengan karakteristik narapidana.

Adapun penggolongan narapidana sebagaimana yang tercantum dalam Pasal 12 UU No 12 Tahun 1995 memang perlu, baik dilihat dari segi keamanan dan pembinaan serta menjaga pengaruh negatif yang dapat berpengaruh terhadap narapidana lainnya. Berdasarkan penggolongan umur, dimaksudkan penempatan narapidana yang bersangkutan hendaknya dikelompokkan yang usianya tidak jauh berbeda, misalnya lapas anak, lapas pemuda, lapas dewasa. Sedangkan penggolongan berdasarkan jenis kelamin dimaksudkan penetapan narapidana yang bersangkutan dipisahkan antara lapas laki-laki dan lapas wanita.

Penggolongan berdasarkan lama pidana yang dijatuhkan, terdiri dari: (1) narapidana dengan jangka pendek, yaitu narapidana yang dipidana paling lama satu tahun; (2) narapidana dengan pidana jangka sedang, adalah narapidana yang dipidana paling singkat satu tahun dan paling lama lima tahun; dan (3) narapidana dengan pidana jangka panjang, yaitu narapidana yang dipidana di atas lima tahun. 
Dengan adanya pengelompokkan ini maka pembinaan yang dilakukan harus melihat dari segi lamanya pidana, sehingga pantas pembina dapat memberikan program pembinaan yang tepat sesuai dengan lama pidana yang dijalani oleh narapidana tersebut. Jenis kejahatan juga merupakan salah satu karakteristik ide individualisasi dalam pembinaan narapidana. Untuk itu di dalam melakukan pembinaan terhadap narapidana haruslah dipisah-pisahkan berdasarkan jenis kejahatannya, seperti narkotika, pencurian, penipuan, penggelapan, pembunuhan dan lain-lain. Hal ini dilakukan untuk menghilangkan prisonisasi ${ }^{7}$ atas narapidana. Sebagaimana dikemukakan oleh Djisman Samosir, memang harus diakui bahwa di dalam penjara terjadi prisonisasi atas narapidana, artinya narapidana itu tepengaruh oleh nilai-nilai yang hidup di penjara seperti kebiasaan-kebiasaan dan budaya di penjara tersebut. ${ }^{8}$ Selanjutnya Tongat mengatakan upaya ini dilakukan atas pertimbangan untuk memperkecil kemungkinan komunikasi antara penjahat kelas kakap dengan para penjahat semula. ${ }^{9}$ Adapun tujuannya mencegah agar jangan terjadi pemaksaan pengaruh dari narapidana yang satu terhadap narapidana lainnya, maupun bentuk pemerasan terlebih-lebih prisonisasi. Untuk itu maka narapidana ditempatkan dalam ruangan yang berbeda-beda sesuai dengan jenis kejahatan yang mereka lakukan. Berdasarkan jenis kejahatan ini maka dilakukan pembinaan yang sesuai dengan narapidana agar dapat mengembalikan narapidana menjadi manusia yang baik dan berguna.

Kalau dilihat dari Pasal 12 UU No. 12 Tahun 1995 tentang Pemasyarakatan ini, maka narapidana ditempatkan dan dibina berdasarkan karakteristiknya sebagaimana disebutkan di atas, sehingga tujuan pembinaan dapat tercapai. Namun, dalam pelaksanaanya, tidak sesuai dengan isi Pasal 12 sebagaimana yang tercantum dalam UU No. 12 Tahun 1995 tersebut, karena jumlah narapidana melebihi kapasitas sehingga penempatan narapidana berdasarkan umur, jenis kejahatan, dan lamanya pidana tidak dapat terwujud. Demikian juga dalam hal pembinaan narapidana, tidak dipisah-pisahkan antara narapidana narkotika dengan narapidana pencurian maupun yang lainnya, sehingga bentuk dan cara pembinaannya sama untuk seluruh narapidana. Hal ini dilakukan karena diantaranya dana yang tersedia sangat minim, jumlah petugas yang melakukan pembinaan juga terbatas, dan peralatan yang tersedia untuk melakukan pembinaan juga terbatas. Dengan

\footnotetext{
${ }^{7}$ Prisonitation (Prisonisasi) adalah istilah yang digunakan oleh TP. Morris dalam bukunya yang berjudul "Pentoville" (1963) untuk menggambarkan tingkah laku nyata narapidana yang bertujuan untuk menyesuaikan diri dengan kehidupan penjara namun sebenarnya mereka menolak untuk mentaati aturan.

${ }^{8}$ Suwarto, Jurnal Equality, Vol. 12 No. 2 Agustus 2007, Ide Indivudualisasi Pidana Dalam Pembinaan Narapidana Dengan Sistem Pemasyarakatan.

${ }^{9}$ Ibid.
} 
demikian pembinaan narapidana berdasarkan Pasal 12 UU No. 12 Tahun 1995 tentang Pemasyarakatan tidak dapat dilaksanakan, sehingga tujuan pembinaan sesuai dengan sistem pemasyarakatan tidak dapat dilaksanakan, sehingga tujuan pembinaan sesuai dengan sistem pemasyarakatan tidak terwujud.

Untuk itu pembinaan narapidana harus disesuaikan dengan karakteristik narapidana atau sesuai dengan Pasal 12 UU No. 12 Tahun 1995 tentang Pemasyarakatan. Lembaga Pemasyarakatan dikembangkan/ ditingkatkan untuk menampung jumlah narapidana, agar penempatan narapidana sesuai dengan isi Pasal 12 tersebut, seperti narapidana yang terlibat dalam kasus narkoba ditempatkan pada satu ruangan khusus narkoba, dan narapidana pencurian dalam satu ruangan, demikian juga dengan narapidana lainnya, sehingga tidak bercampur baur. Begitu juga dalam hal pembinaan narapidana, yakni pembinaan narapidana khusus narkoba berbeda dengan pembinaan narapidana pencurian, penggelapan, pembunuhan, dan lain-lain, sehingga bentuk dan cara pembinaannya disesuaikan dengan jenis kejahatan dan lamanya pidana yang dijatuhkan. Hal ini dilakukan agar pembinaan itu benar-benar disadari dan dimengerti oleh narapidana sehingga tujuan pembinaan dapat tercapai.

Untuk mencapai tujuan tersebut, tidak terlepas juga dari kualitas dan kuantitas petugas Lembaga Pemasyarakatan, serta peran serta masyarakat/pihak swasta.

\section{Tujuan Pemidanaan dan Tujuan Pemasyarakatan dalam Penggolongan Narapidana}

Pidana penjara dapat mengandung sifat ganda yaitu sebagai sanksi pidana dapat dirasakan tidak enak bagi yang terkena yang menunjukkan sifat dasar yang statis, dan dalam pelaksanannya tumbuh berbagai variasi dalam memasuki falsafah pembinaan (treatment philosophy) yang menunjukkan sifat yang dinamis dan atau plastis ${ }^{10}$.

Pemasyarakatan adalah kegiatan untuk melakukan pembinaan warga binaan pemasyarakatan berdasarkan sistem, kelembagaan, dan cara pembinaan yang merupakan bagian akhir dari sistem pembinaan dalam tata peradilan pidana ${ }^{11}$.

Pada Tahun 1963, konsep pemasyarakatan diajukan oleh menteri kehakiman, Sahardjo, yaitu:

a. singkat tujuan penjara ialah: pemasyarakatan, yang mengandung makna bahwa tidak hanya masyarakat yang diayomi terhadap diulanginya

\footnotetext{
10 Bambang Poernomo, Pelaksanaan Pidana Penjara dengan System Pemasyarakatan, (Yogyakarta: Liberty, 1986), hlm. 73.

${ }^{11}$ Pasal 1 ayat (1) UU No. 12 Tahun 1995 tentang Pemasyarakatan.
} 
perbuatan jahat oleh terpidana, melainkan juga orang-orang yang telah sesat diayomi dan diberikan bekal hidup, sehingga menjadi kawula yang berfaedah di dalam masyarakat Indonesia; dan

b. pidana penjara di samping menimbulkan rasa derita pada terpidana karena kehilangan kemerdekaan bergerak, membimbing agar terpidana bertobat, mendidik agar supaya dia menjadi anggota masyarakat sosialisme yang berguna ${ }^{12}$.

Lembaga pemasyarakatan adalah tempat untuk melaksanakan pembinaan narapidana dan anak didik pemasyarakatan ${ }^{13}$.

Dalam rangka pembinaan, lembaga pemasyarakatan terdapat penggolongan narapidana berdasarkan:

a. umur;

b. jenis kelamin;

c. lama pidana yang dijatuhkan; dan

d. kriteria lainnya sesuai dengan kebutuhan atau perkembangan pembinaan $^{14}$

John Howard memperjuangkan perhatian terhadap perlakuan narapidana dengan manusiawi, juga usaha-usaha untuk memberikan arti yang sebenarnya dari pemidanaan adalah membina para narapidana agar setelah habis masa pidananya, dapat kembali ke masyarakat dengan lebih baik. Pembinaan yang dilakukan meliputi pembinaan fisik dan mental, pendidikan umum, kesehatan, dan lain sebagainya ${ }^{15}$. yaitu: ${ }^{16}$

Tujuan pembinaan adalah pemasyarakatan, dapat dibagi dalam tiga hal

a. setelah keluar dari lembaga pemasyarakatan tidak lagi melakukan tindak pidana;

b. menjadi manusia yang berguna, berperan aktif dan kreatif dan kreatif dalam membangun bangsa dan negaranya; dan

c. mampu mendekatkan diri kepada Tuhan Yang Maha Esa dan mendapatkan kebahagiaan di dunia maupun di akhirat.

\section{a. Penggolongan Narapidana Berdasarkan Tujuan Pemidanaan}

Teori pemidanaan dalam teori absolut merupakan akibat mutlak yang harus ada sebagai suatu pembalasan kepada orang yang melakukan kejahatan ${ }^{17}$.

\footnotetext{
${ }^{12}$ Susanto, Kriminologi, (Yogyakarta: Genta Publisher, 2011), hlm. 111.

${ }^{13}$ Pasal 1 ayat (3) UU No. 12 Tahun 1995 tentang Pemasyarakatan.

${ }^{14}$ Pasal 12 UU No 12 Tahun 1995 tentang Pemasyarakatan.

${ }^{15}$ C.I. Harsono Hs, Op.Cit., hlm. 46.

${ }^{16}$ Ibid., hlm. 47.

${ }^{17}$ Muladi dan Barda Nawawi Arief, Teori-Teori dan Kebijakan Pidana, (Bandung: Alumni, 2010), hlm. 12.
} 
Sedangkan dalam teori relative, pidana sebagai sarana untuk melindungi kepentingan masyarakat. maka teori ini juga disebut teori perlindungan masyarakat. Pidana bukan sekedar pembalasan tetapi memunyai tujuan-tujuan tertentu yang bermanfaat, oleh karena itu teori ini juga disebut teori tujuan (utility teori) ${ }^{18}$.

Pidana dijatuhkan bukan karena orang membuat kejahatan melainkan supaya orang jangan melakukan kejahatan. Selain itu teori relatif memunyai tujuan penjatuhan pidana yang salah satunya adalah memperbaiki sikap agar bisa menjadi orang baik.

Tujuan pemidanaan menurut Rancangan Kitab Undang-undang Hukum Pidana adalah: ${ }^{19}$

a) mencegah dilakukannya tindak pidana dengan menegakkan norma hukum demi pengayoman masyarakat,

b) memasyarakatkan terpidana dengan mengadakan pembinaan sehingga menjadi orang yang baik dan berguna;

c) menyelesaikan konflik yang ditimbulkan oleh tindak pidana, memulihkan keseimbangan, dan mendatangkan rasa damai dalam masyarakat; serta

d) membebaskan rasa bersalah pada terpidana.

Bentuk dari memasyarakatkan terpidana dengan penggolongan narapidana yang sesuai memudahkan pembina lapas melakukan pembinaan agar bisa menjadi orang yang lebih baik. Sebagai contoh penggolongan berdasarkan lama pidana yang dijatuhkan sesuai dengan tindak pidananya akan menghapus bahwa lapas adalah sekolah tinggi ilmu kejahatan. Dalam hal ini penggolongan yang sesuai adalah penggolongan berdasarkan masa pidana dan jenis kejahatan.

Penggolongan narapidana berdasarkan jenis kelamin dan umur juga bisa dilakukan untuk mencegah terjadinya tindak pidana. Contohnya pelecehan seksual dan penganiayaan.

\section{b. Penggolongan Narapidana Berdasarkan Tujuan Pemasyarakatan}

Berdasarkan Rancangan Kitab Undang-undang Hukum Pidana yang terdapat dalam Pasal 54, tujuan pemasyarakatan adalah sebagai berikut:

1) orang yang tersesat harus diayomi dengan memberikan bekal hidup sebagai warga yang baik dan berguna dalam masyarakat;

2) penjatuhan pidana bukan tindakan balas dendam dari negara;

3) rasa tobat tidak dapat dicapai dengan cara menyiksa, tetapi dengan bimbingan;

4) negara tidak berhak membuat seorang terpidana menjadi lebih buruk atau lebih jahat apabila dibandingkan dengan sebelum masuk penjara;

\footnotetext{
${ }^{18}$ Ibid, hlm. 16.

${ }^{19}$ Pasal 54 RUU KUHP.
} 
5) selama kehilangan kemerdekaan bergerak, narapidana (warga binaan) harus dikenalkan kepada masyarakat dan tidak boleh diasingkan dari masyarakat;

6) pekerjaan yang diberikan kepada narapidana tidak boleh bersifat sekedar mengisi waktu atau hanya diperuntukan bagi kepentingan lembaga atau negara, tetapi ditujukan untuk kepentingan pembangunan negara;

7) bimbingan dan didikan harus berdasarkan azas terkandung dalam pancasila;

8) tiap orang adalah manusia dan harus diberlakukan sebagai manusia, walaupun tersesat tetapi tidak boleh ditunjukan bahwa dia sebagai penjahat;

9) narapidana hanya dijatuhi hilang kemerdekaan; dan

10) sarana fisik lembaga pemasyarakatan saat ini merupakan salah satu hambatan dalam pelaksanaan pidana dengan sistem pemasyarakatan.

Dalam tujuan pemasyarakatan beberapa poin menyebutkan bimbingan dan terdapat juga kata didikan. Bimbingan dan didikan akan lebih maksimal jika ada penggolongan narapidana. Sebagai contoh penggolongan narapidana berdasarkan umur. Narapidana yang masih anak-anak atau usia di bawah 18 tahun (anak didik pemasyarakatan), pembinaan dan didikannya tentu berbeda dengan usia yang lebih tua. Mereka mendapat perlakuan khusus sehingga harus dibina dalam lapas anak.

\section{Penutup}

Berdasarkan dari uraian di atas, maka ide individualisasi pidana dalam pembinaan narapidana termasuk narapidana wanita dengan sistem pemasyarakatan sebenarnya sudah merupakan suatu realita, sebagai hasil akhir perkembangan hukuman penjara dalam perkembangan hukum pidana modern, dan Indonesia sudah memulainya di akhir tahun 1960-an. Sedangkan dari segi dasar hukum, Indonesia telah mengundangkan UndangUndang Nomor. 12 Tahun 1995 tentang Pemasyarakatan yang telah menjadi hukum positif dan harus dilaksanakan untuk mencapai tujuan pemasyarakatan, yakni mengembalikan narapidana ke tengah-tengah masyarakat menjadi manusia yang baik dan berguna dan tidak mengulangi tindak pidana sehingga dapat hidup secara wajar dan bertanggung jawab.

Penggolongan narapidana yang sesuai dengan tujuan pemasyarakatan berkaitan dengan bimbingan dan didikan. Bimbingan dan didikan akan lebih maksimal jika ada penggolongan narapidana. Sebagai contoh penggolongan narapidana berdasarkan umur. Narapidana yang masih anak-anak atau usia di bawah 18 tahun (anak didik pemasyarakatan), pembinaan dan didikannya berbeda dengan usia yang lebih tua. Mereka mendapat perlakuan khusus sehingga harus dibina dalam lapas anak. 


\section{Daftar Pustaka}

\section{Buku}

Arief, Barda Nawawi, 2010, Kebijakan Legislatif Dalam Penanggulangan Kejahatan Dengan Pidana Penjara, Yogyakarta: Genta Publishing.

Bahri, Syaiful, 2009, Perkembangan Stelsel Pidana Indonesia, Yogyakarta: Total Media.

Hs, C.I. Harsono, 1995, System Baru Pembinaan Narapidana, Jakarta: Djambatan.

Muladi dan Arief: Barda Nawawi, 2010, Teori-Teori dan Kebijakan Pidana, Bandung: Alumni.

Poernomo, Bambang, 1986, Pelaksanaan Pidana Penjara dengan System Pemasyarakatan, Yogyakarta: Liberty.

Sakidjo, Aruan, dan Poernomo, Bambang, 1990, Hukum Pidana Dasar Aturan Umum Hukum Pidana Kodifikasi, Yogyakarta: Ghalia Indonesia.

Susanto, 2011, Kriminologi, Yogyakarta: Genta Publisher.

Suwarto, Jurnal Equality, Vol. 12 No. 2 Agustus 2007, Ide Indivudualisasi Pidana Dalam Pembinaan Narapidana Dengan Sistem Pemasyarakatan.

\section{Undang-Undang}

Rancangan Undang-Undang Kitab Undang-Undang Hukum Pidana. Undang-Undang Nomor 12 Tahun 1995 tentang Pemasyarakatan. 